\title{
PHYSICAL ACTIVITY OF ELDERLY PEOPLE ON THE EXAMPLE OF THE COURSE PARTICIPANTS AT THE UNIVERSITY OF THE THIRD AGE IN KROSNO
}

\author{
Dariusz Jurczak, Adam Przybysz
}

\author{
State Higher Vocational School in Krosno
}

Jurczak D., Przybysz A. (2014) Physical activity of elderly people on the example of the course participants at the University of the Third Age in Krosno. Health Problems of Civilization 2 (8), p. 20-27

\begin{abstract}
Summary: Regular physical activity plays a very important role at every stage of human life. Its comprehensive impact also in terms of health can not be overestimated. Unfortunately, despite many activities for the promotion of physical culture, as reported by several studies and publications, still as a society we are not very physically active. The aim of the study was to answer the questions regarding the assessment of physical activity of older course participants at Krosno University of the Third Age. The research was conducted in October 2012. It was attended by 74 people. The main research method was a diagnostic survey and questionnaire. Based on the obtained results it can be concluded that the University provides its listeners access to a wide range of different kinds of physical activity, as evidenced by the fact that over $80 \%$ of them avail of these offers. Over $40 \%$ of respondents note that the time they spend on physical activity does not exceed two hours per week. On the other hand, $15 \%$ do so more than five hours per week. The most popular forms of physical activity among the respondents include classes in the pool, gym and rallies tours, hiking, biking and Nordic walking. The main impetus motivating older people to engage in physical activity is the need to move, care and attention to their own health.
\end{abstract}

Key words: physical activity and exercise, health, elderly person, university of the third century

\section{Introduction}

Nothing ruins a man as much as his continuous stillness Aristotle

Words expressed over two thousand years ago by the Greek philosopher are very valid even in today's times. The unsatisfactory state of physical activity among the population (this problem is already visible among the youngest children) is one of the main factors because of which people often suffer from diseases of civilization of the cardiovascular system (heart attacks and strokes, hypertension), coronary heart disease, atherosclerosis, diabetes, cancer, hypertension, obesity (Drabik 1995). Of course, the causes of these diseases have different substrate including genetic, but certainly also one of the main sources is insufficient or total lack of movement (Jethon, Wierzbicka-Women 2005). During the revival time Wojciech Oczko, a prominent humanist, court physician of King Stefan Batory in his work on O różnych przypadłościach „ciała ludzkiego" (1581) stressed the importance of diet and health advantages of physical exercise, which he recognized not only as a prophylactic measure, but also as the clinical treatment. He wrote then: „Physical activity is able to replace all the drugs put together, but all drugs are no substitute of an activity” a phrase that continues to be of meaningful significance (Gaj, Hądzelek 1997). In the times in which we live, when quite frequently many people have no contact with physical activity - the reasons for this have multiple sources, among which the progress of civilization ought to be mentioned (the development of technology, computerization, communication) as well as convenient and consumptive attitude to life, excess of professional duties including overload of work or study (Woynarowska 2010). As never before, physical activity should be promoted as it is a moderate and regular exercise which can be an antidote to these diseases (Kopczyńska-Sikorska 1981, Bielski, 1997). The movement creates an opportunity for this to alleviate or remove many path-

\footnotetext{
Adress for correspondence: Adam Przybysz, State Higher Vocational School in Krosno, Rynek 1, 38-400 Krosno, e-mail: adamkrosno@onet.pl, phone +48 (13) 4375500

Tables: 0, Figures: 9, References: 18, Full text PDF www.hpc.edu.pl Copyright (C) Pope John Paul II State School of Higher Education In Biała Podlaska, Sidorska 95/97, 21-500 Biała Podlaska Indexation: Index Copernicus, Polish Ministry of Science and Higher Education. This is an open-access article distributed under the terms of the Creative Commons Attribution Non-commercial License (http://creativecommons. org/licenses/by-nc/3.0), which permits use, distribution, and reproduction in any medium, provided the original work is properly cited, the use is non-commercial and is otherwise in compliance with the license.
} 
ogens (Drabik J., Drabik P. 1997 Woźny 2013). A special request should be addressed to the parents, because they should be aware that the development of disorders and diseases, which are triggered by contemporary life, takes place slowly (they may even remain in a latent state for a long time) and therefore they are not immediately seen in children, and their dynamics is usually disclosed in the period of maturity (Woynarowska 2001).Unfortunately, nowadays we very often hear that because of the excessive duties we do not have time for sport, physical activity, walking, ridding a bicycle, recreation and tourism (Rochowicz 2008). These words are not just said by the adults, but also very often by the youngest of us. It seems that the problem is not the actual lack of time, but it exists in other obstacles, such as the psyche. People do not feel the need for physical activity, the need to spend time outdoors. This need should stem from the internal motivation, from the awareness and deliberate desire to do something for health (Demel 1980 Cendrowski 1997), as it often happens that a young man completes two specializations, has a lot of knowledge, but the state of his health (at the age of twenty-several years old) qualifies him for benefits, or sickness pensions (Pańczyk, Warchoł 2011).

The aim of this study was to answer the questions regarding the assessment of physical activity of older course participants of the Krosno University of the Third Age. Based on numerous published literature, reports, conferences and symposia, discussions on the state of health of the Polish population, it is clear that physical activity among the population is not very satisfactory (Cendrowski 1997, Cynarski, Bajorek 2009, Osinski 2011). For many years, studies have shown that very few, because just over $10 \%$ of the adult population has a purposeful, conscious and systematic contact with the physical activity (Bergier 2012).

\section{Materials, methods and research results}

The study was conducted in October 2012 among course participants of Krosno University of the Third Age (further called KUTW). The research method was a diagnostic survey and questionnaire (Palka 2010). The research included 74 people (including 62 women and 12 men) who responded to the questionnaire survey. A set of questions with both open and closed questions related mainly to the attitude of participants to physical activity.

As it is visible on Figure 1 KUTW course participants in the vast majority have a positive attitude toward physical activity. This may prove that the importance of physical activity among older people plays a significant role.

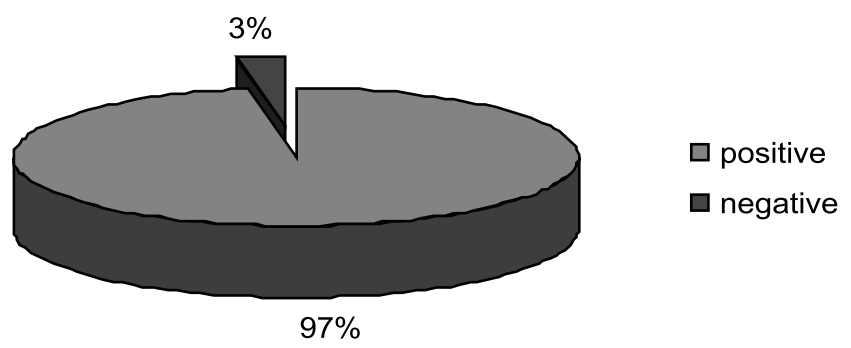

Figure 1. Relationship towards physical activity $(\mathrm{N}=74)$

Among all respondents, $45 \%$ of respondents indicated professional activity. Research shows that the responsibilities associated with work do not constitute a substantial obstacle to the cultivation of physical activity. Nearly half of the surveyed students of KUTW are people who are still active professionally. In this situation, it is clear that what determines whether the weekly timetable will include physical activity is the need and desire to practice any form of movement to a greatest extent, which undoubtedly is also affected by awareness of the importance of movement in human life.

The fact that $96 \%$ of respondents in their replies declared that they are physically active should be seen as very positive outcome - including 39\% expressing it in a decisive manner. Only $4 \%$ of respondents indicated a lack of physical activity in their lives.

The primary impetus for the elderly is the need for physical activity movement. Care for one's own health plays a very important role in the implementation of the elderly to leisure activities. It is worth noting that the response in this regard corresponds with what has been said before, that the need for exercise and care for one's health are the main factors motivating the respondents to attend sports facilities. Percentage of different stimuli of older people in physical activity has been presented in Figure 2. 


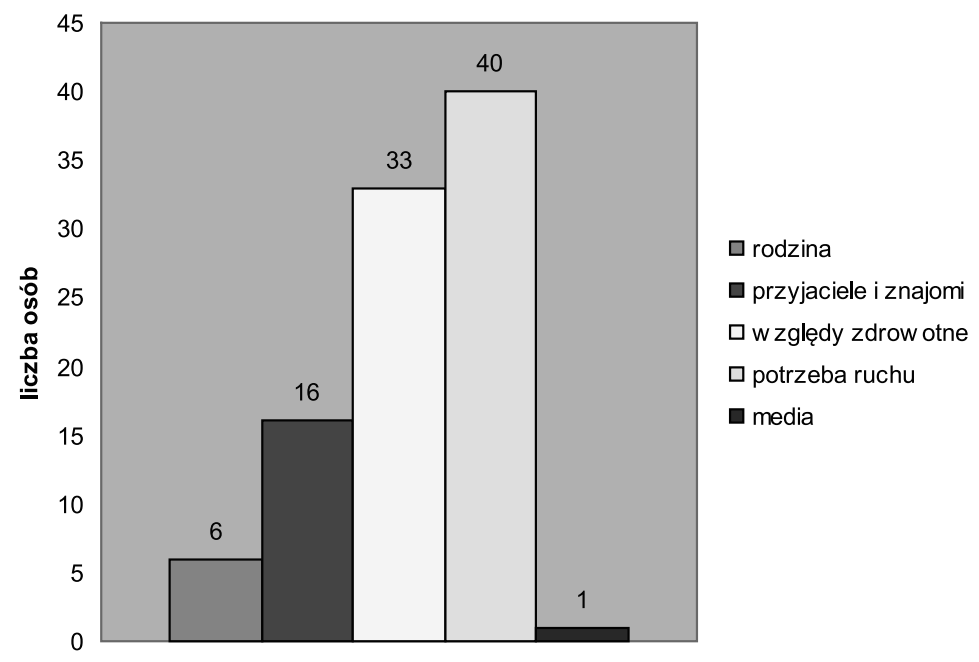

Figure 2. Factors stimulating physical activity among course participants (N=74)

As it is obvious from the answers to the question as to how the students mostly spend their free time, the most popular form of activity is work in the garden (31 replies). Walking is also very popular (30 responses). In addition, participants are very happy to meet up with friends and colleagues, and spend their free time reading books (23 responses). Undoubtedly, the reason that a lot of them are fond of reading may be due to the fact that almost half of the students are people with university education.

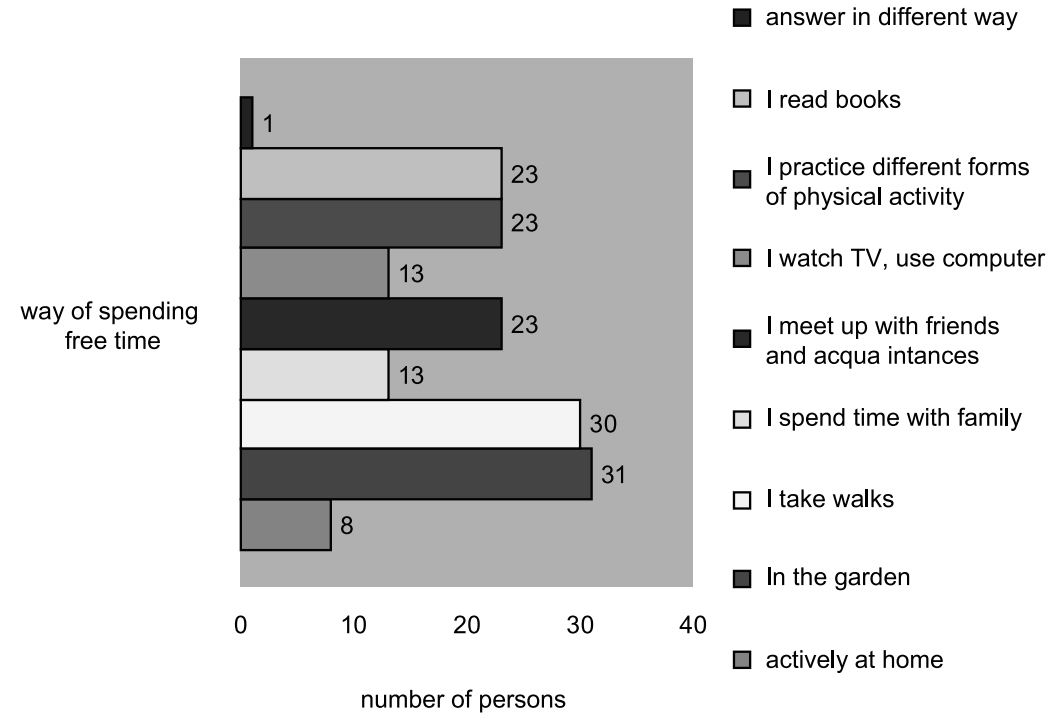

Figure 3. Ways of sending free time among participants $(\mathrm{N}=74)$

On the other hand, Figure 4. presents forms of physical activity that students prefer. As it is clear from the below answers the most common form of activity is hiking (54 responses) and cycling (38 responses); 22 people opted for Nordic walking. The least interest among the respondents are the team games, while football was mentioned only by 3 people. 1 person mentioned basketball. Lack of interest in these disciplines can probably be explained by the fact that the vast majority of the respondents were women (84\%). Besides that, 4 persons declared that they cultivate other activities, which include: gymnastics, aerobics and dance. It is worth noting that only one person indicated not performing any form of activity. 


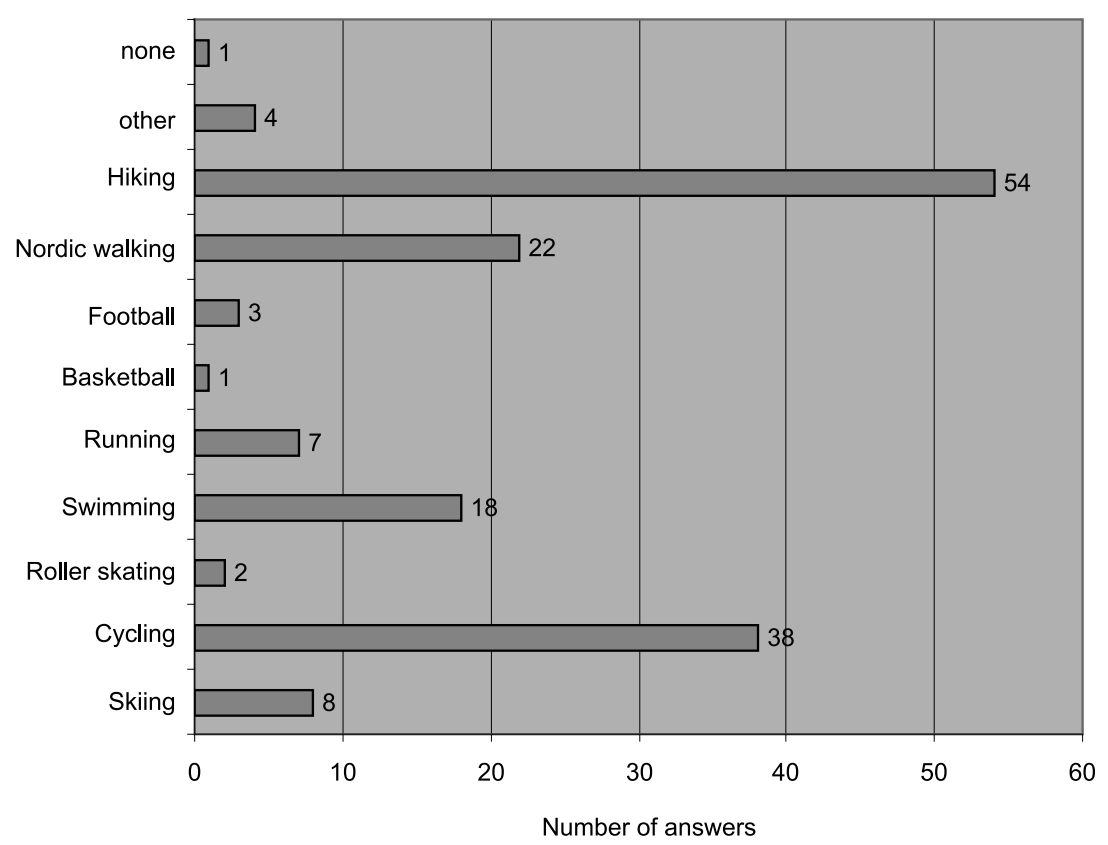

Figure 4. Forms of physical activity preferred by the participants $(\mathrm{N}=74)$

Elderly people wanting to practice physical activity often face different barriers and obstacles, which to some extent certainly limit the possibility of spending free time. It is clear from the study (Figure 5), that the biggest difficulty for the elderly in the systematic cultivation of physical activity is thelack of perseverance and consistency (22\%) and an excess of household duties and family obligations (16\%). Another barrier is reluctance to exercise (15\%). The respondents indicated poor health condition on the fourth place (13\%). Only $9 \%$ of respondents as a barrier to practicing physical activity considered insufficient funds. The fact that only a small number of respondents drew attention to the financial aspect undoubtedly stems from the fact that KUTW to a large extent provides its students with possibility of physical activation in an organized manner at a symbolic cost. These classes are enjoying great interest of the students.

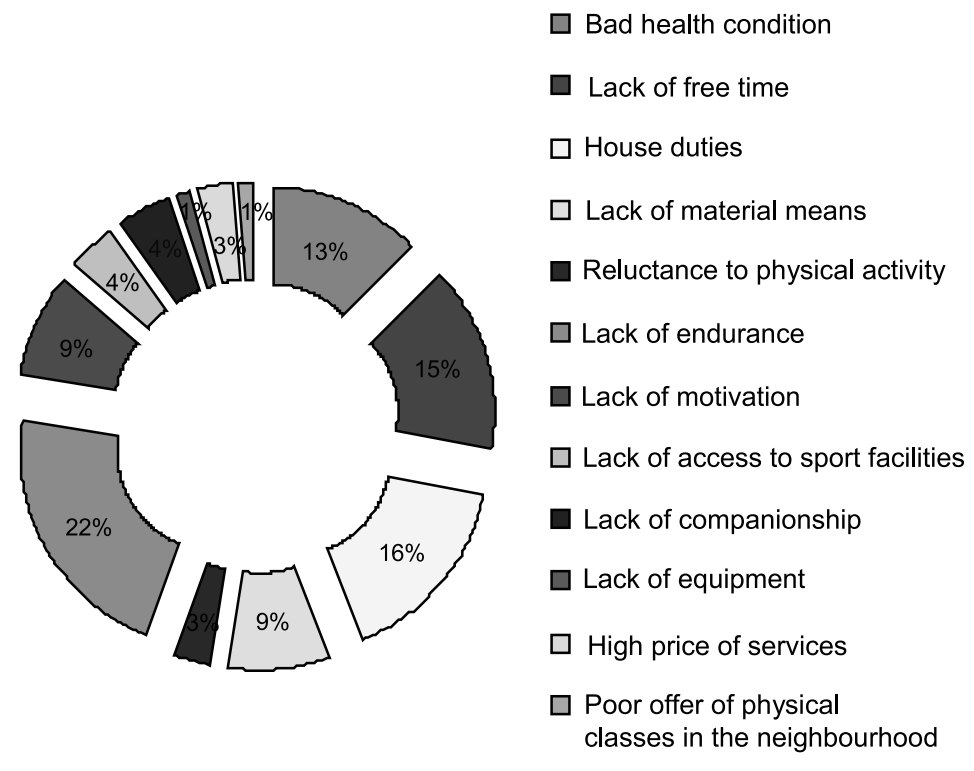

Figure 5. Barriers limiting physical activity among recipients $(\mathrm{N}=74)$

As per the obtained results, a lot, as much as $41 \%$ of the surveyed persons stated that the amount of time per week they spend on physical activity does not exceed 2 hours. In this situation, it is worth noting that this is the exact amount of time that classes in gymnastics or swimming pool classes take. Hence, it should be noted that for this large group, the activities organized by KUTW become the only opportunity to practice sports. The fact that $34 \%$ of respondents practice sports up to 5 hours per week, while $25 \%$ of respondents do it more than 5 hours a week is comforting. 
Krosno University of the Third Age makes efforts in order to activate its members to physical activity by organizing for them a number of physical activities. The most popular forms include hiking and biking tours, which in the summer are organized periodically (at least once a month). In the winter months they are joined also by sleigh ridding. Particular participation of the students in organized activities is illustrated in Fig. 6

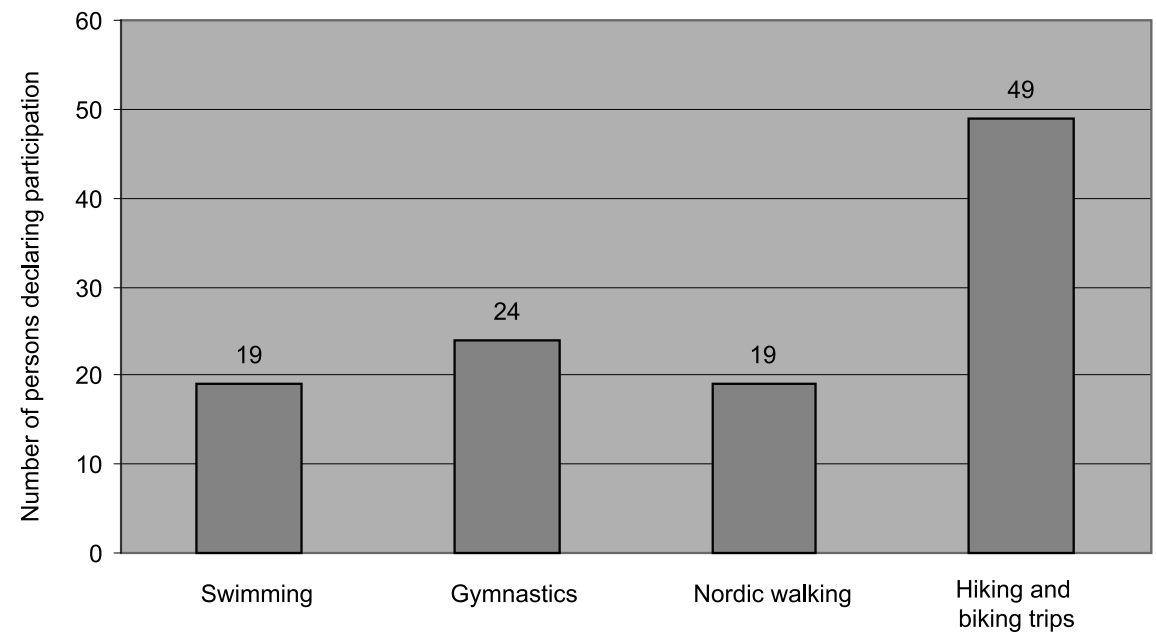

Figure 6. Forms of physical activity preferred by students $(\mathrm{N}=74)$

A positive aspect that should be considered is that $81 \%$ of course participants systematically and regularly attend courses of their choice. This condition is also confirmed by leading teachers who assess attendance and systematic participation at a satisfactory level. The fact that as many as $62 \%$ of respondents declared participation in various forms of physical activity outside the University is satisfactory.

Figure 7 illustrates all forms of physical activity undertaken by the respondents outside of the classroom at the University. A detailed description is presented in Table 1

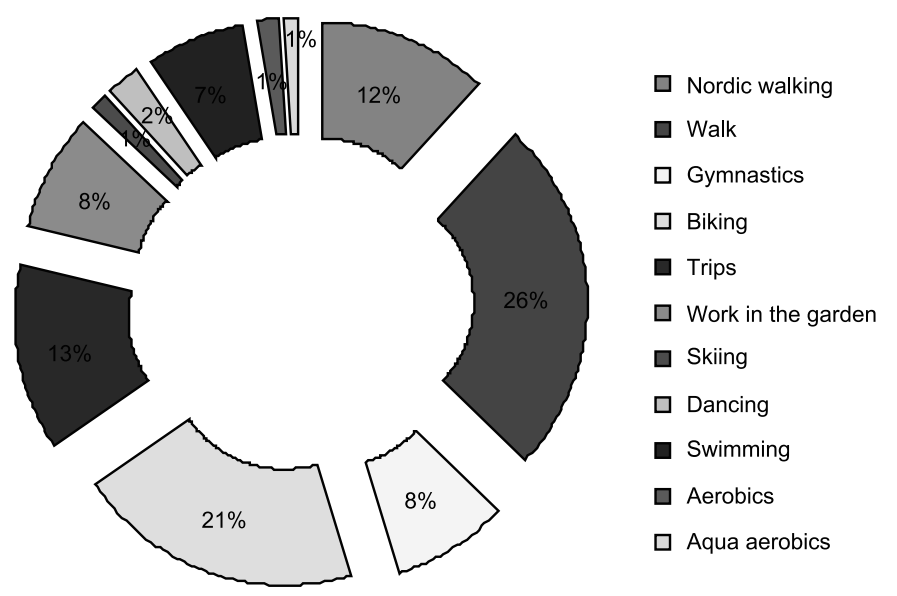

Figure 7. Forms of physical activity taken up by course participants of KUTZ (N=74)

Table 1. Participation of students in forms of physical activity outsider KUTW (N=74).

\begin{tabular}{|l|c|l|c|}
\hline Conducted themselves & Organized & N \\
\hline Form of activity & $\mathbf{N}$ & Form of activity & 9 \\
\hline walk & 18 & trips & 5 \\
\hline Bike ride & 16 & Swimming pool & 4 \\
\hline Walking and cycling tours & 9 & nornic walking & 1 \\
\hline gymnastics & 6 & gymnastics & 1 \\
\hline nordic walking & 6 & aerobics & \\
\hline gardeining & 6 & & \\
\hline
\end{tabular}




\begin{tabular}{|l|c|l|c|}
\hline Swimming pool & 5 & & \\
\hline Skiing & 1 & & \\
\hline Dancing & 1 & & \\
\hline aerobics & 1 & & \\
\hline TOTAL & $\mathbf{6 9}$ & & $\mathbf{2 0}$ \\
\hline
\end{tabular}

As is clear from the data presented in Figure 7. and Table 1, out of the 44 people who have declared participation in additional forms of activity it was indicated 69 times that participants organize their own free time. The most popular form of activity in this scope is a walk (18 responses) and cycling (16 replies). While the least popular disciplines are: skiing, dancing and aerobics ( 1 reply each). On the other hand, among the organized forms trips are the most popular (9 responses), and the least popular activities are gymnastics and aerobics (1 reply each). It should be noted that in this regard the question had an open form, respondents could give multiple answers that were not imposed on them (above types of disciplines were given by the respondents by themselves).

The data in Table 2 show how often a week the course participants exercise physical activity outside of KUTW. Out of 42 people who declared that they are active outside the discussed institution, 12 people noted that they perform it five times a week, while 18 people noted they perform it one or two times a week.

Table 2. Frequency of participating by the respondents in forms of physical activity outsider KUTW (N-74)

\begin{tabular}{|l|c|}
\hline NUMBER OF CLASSES PER WEEK & N \\
\hline once & 9 \\
\hline twice & 9 \\
\hline 3 times & 5 \\
\hline 4 times & 5 \\
\hline 5 times & 12 \\
\hline More than 5 times a week & 4 \\
\hline TOTAL & $\mathbf{4 4}$ \\
\hline
\end{tabular}

Sources of motivation for practicing physical activity were presented in Figure 8. The most common reason for participation in physical activity among the respondents is the care about their own performance and physical condition (28\%). The desire to improve health status was of very high importance here (21\%), just as having a good leisure time $(19 \%)$.
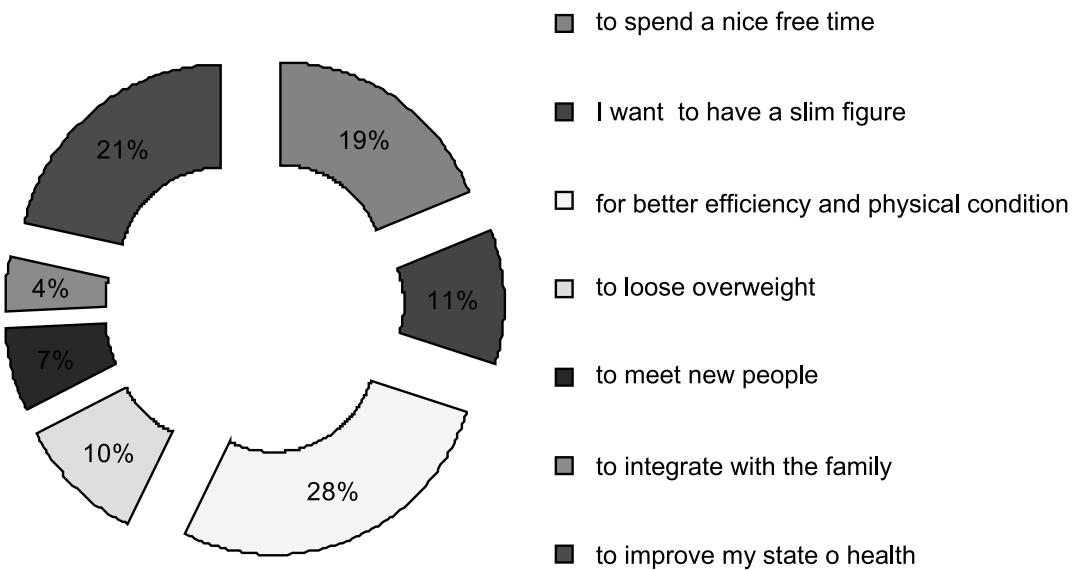

Figure 8. Reasons for performing physical activity among participants $(\mathrm{N}=74)$

The fact that $97 \%$ of respondents are satisfied with the state of their physical fitness (including $55 \%$ of respondents indicating that they were satisfied, while $44 \%$ noting they were rather satisfied) is optimistic. This desirable situation must undoubtedly be combined with a generally increasing promotion and popularity of physical activity among the society with a broader than in the past access to recreation, and, as indicated in the above studies, greater than ever consciousness of the elderly regarding the need for active leisure, among others, through physical activity. 
In addition, among the positive factors that have an impact on physical efficiency of the respondents one should consider lack of too frequent hanging out time in front of computer and television - the data is presented in Figure 9. As can be seen, the number of hours spent a day sitting in front of the TV and the computer is small. Hence, students can devote this time (for the benefit of their health and well-being) to active rest.

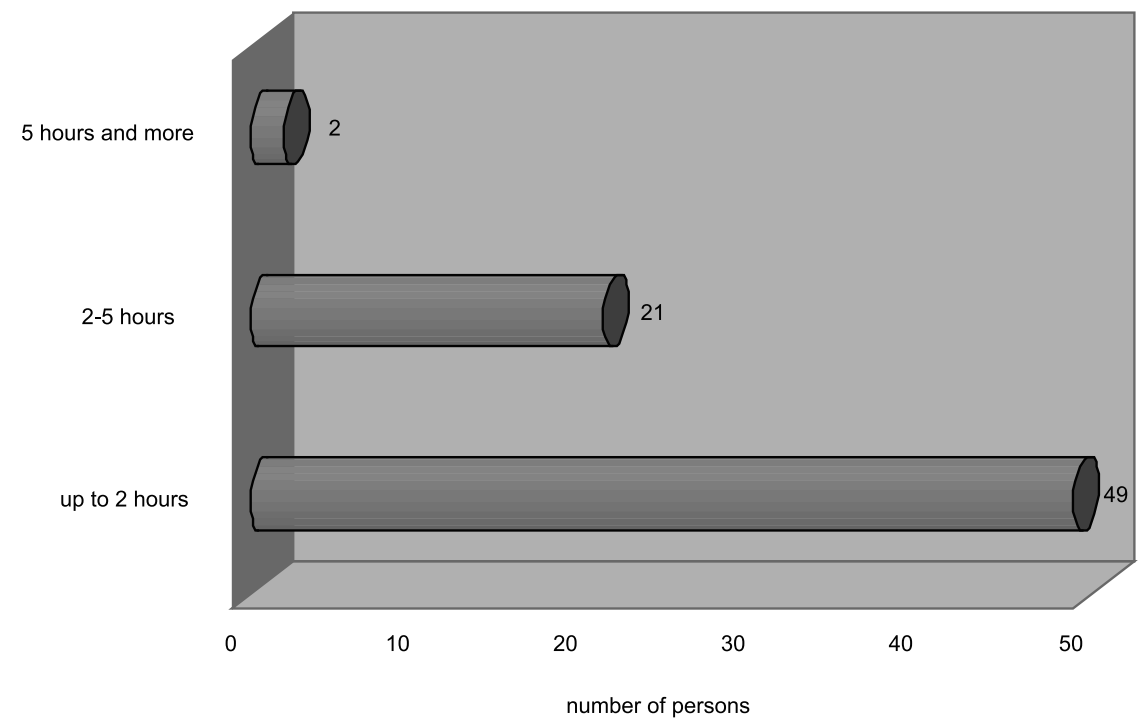

Figure 9. Number of hours spent daily in a pitting position, including watching TV and at the computer $(\mathrm{N}=74)$

\section{Conclusions}

1. Krosno University of the Third Age, in its multifaceted statutory activity, carries out in an organized and systematic way many projects that promote active forms of leisure and healthy lifestyle, and the most popular forms of physical activity are classes in the pool, gym and trips and rallies (hiking and cycling). These classes are regularly attended by more than $80 \%$ of respondents.

2. The vast majority of respondents (97\%) demonstrates a positive attitude towards physical activity, and the primary impetus motivating elderly people to work in this field is the need to exercise and care and attention to their own health (fitness and physical condition).

The internal intention of the respondents to exercise can also be judged from the fact that only the small number of them $(8.1 \%)$ pointed to the family, while the media as a stimulus appealed to one person.

3. Students of KUTW spend free time in a variety of ways. Among the many forms garden work and walking are the leaders (40\% of responses), various forms of physical activity and reading books and gatherings with friends and family ( $31 \%$ response rate). And although we live in the world of television and information technology - the Internet and television, the fact that only a few (17\% of respondents) dedicate their free time to sit in front of the media of social communication is comforting.

4. Although almost half of the students outside the University is still professionally active, the majority of respondents (96\%) say their physical activity (in it 39\% highlight this decisively). The good news is that over 60\% of respondents have contact with physical activity outside the University. Also the fact that 34\% of respondents spend on it up to 5 hours a week, while $25 \%$ do so more than five hours per week is relatively satisfactory. However, it should be emphasized that a large number, as many as $41 \%$ of the respondents declare that the amount of time during the week spent by them on physical activity does not exceed two hours per week. Hence, it should be noted that for this large group activities organized by KUTW become the only opportunity to participate in any sports. 5. Among several sport disciplines - mentioned by students as a form of physical activity, hiking is the most popular (72\% response rate). More than half of the respondents also indicated cycling, while less than 30\% cited Nordic walking and swimming.

6. Among the factors that become to a greater or smaller extent a difficulty for the students of KUTW in the systematic cultivation of their physical activity is the lack of perseverance and consistency (22\%) and the excess of domestic and family duties (16\%) and unwillingness to exercise (15\% ). Over $90 \%$ of respondents do not see any barriers in the financial aspect. Undoubtedly, this situation should be explained by the fact that the University provides its students with access to the material base of the sport free of charge or at a small payment. It should also be noted that in the last decade sports infrastructure in the city of Krosno has significantly improved. 


\section{References:}

1. Bergier J. (2012), Aktywność fizyczna społeczeństwa- współczesny problem (przegląd badań). Człowiek i Zdrowie, Tom VI, nr 1, s. 3-5.

2. Bielski J. (1997), Życie jest ruchem, Warszawa.

3. Cendrowski Z. (1997), Przewodzić innym, Poradnik dla liderów zdrowia i sportu, Fundacja Promo-Lider, Warszawa.

4. Cendrowski Z. (1993), Dekalog zdrowego stylu życia, Fundacja Promo-Lider, Warszawa.

5. Cynarski W., Bajorek W. (red.) (2009), Problemy kultury fizycznej i zdrowotnej w ujęciu holistyczno- humanistycznym, Wydawnictwo Uniwersytetu Rzeszowskiego.

6. Demel M. (1980), Pedagogika zdrowia, WSiP, Warszawa.

7. Drabik J. (1995), Aktywność fizyczna w edukacji zdrowotnej społeczeństwa Cześć I, Wydawnictwo AWF Gdańsk.

8. Drabik J., Drabik P. (1997), Wydolność i aktywność fizyczna osób w starszym wieku. Wychowanie Fizyczne i Sport, nr 3, s.47-54.

9. Gaj J., Hądzelek K. (1997), Dzieje kultury fizycznej w Polsce, Poznań.

10. Jethon Z.,Wierzbicka- Damska I. (2005), Zdrowotne znaczenie aktywności ruchowej u osób starszych. W: Znaczenie aktywności ruchowej dla zdrowia, (red.) E. Murawska-Ciałowicz, M. Zatoń, AWF Wrocław.

11. Kopczyńska - Sikorska J. (1981), Znaczenie aktywności fizycznej w ochronie zdrowia człowieka, Pedagogika Polska LVI.

12. Osiński W. (2011), Teoria wychowania fizycznego, AWF Poznań.

13. Palka S. (2010), Podstawy metodologii badań w pedagogice, Wyd. Pedagogika GWP, Gdańsk.

14. Pańczyk W., Warchoł K. (red.) (2011), Nowe - bliższe zdrowiu wychowanie fizyczne, Wydawnictwo Uniwersytetu Rzeszowskiego.

15. Rochowicz F. (2008), Czas wolny uczniów- w świetle aktywności ruchowej i zajęć sedenteryjnych. Wychowanie Fizyczne i Zdrowotne, nr 3, s. 16- 20.

16. Woźny P. (2013), Czy można odrzucić aktywność fizyczną, www.lider.szs.pl/download/268_lider.doc

17. Woynarowska B. (2001), Kształtowanie prozdrowotnego stylu życia ludności w Polsce, AWF Warszawa.

18. Woynarowska B. (2010), Edukacja zdrowotna, Wydawnictwo Naukowe PWN, Warszawa.

Submitted: 23.04 .2014

Accepted: 26.06.2014 